\title{
The interconnection between \\ entrepreneurship and dynamic capabilities: a bibliometric analysis
}

\author{
Giovani Cruzara1', Vivien Mariane Massaneiro Kaniak², Itamir Caciatori Junior33, \\ Rivanda Meira Teixeira 4 \\ ${ }^{1}$ Universidade Federal do Paraná - giovani.cruzara@outlook.com \\ ${ }^{2}$ Universidade Federal do Paraná - vivikaniak@gmail.com \\ 3 Universidade Federal do Paraná - itamirci@gmail.com \\ 4 Universidade Federal do Paraná - rivandateixeira@gmail.com
}

KEYWORDS

Entrepreneurship, Dynamic Capabilities, Bibliometric.

Received 27.01.2020

Reviewed 29.06.2020

Accepted 27.08.2020

ISSN 1980-4431

Double blind review

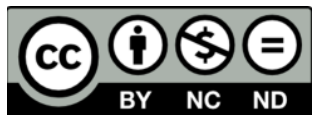

PALAVRAS-CHAVE

Empreendedorismo, Capacidades dinâmicas, Bibliometria.
ABSTRACT

The aim of this study was to map the academic production addressing the themes entrepreneurship and dynamic capabilities. Through bibliometric analysis as a research method and using the WoS database we found 805 papers from which we present an examination of citations, co-citations, most prevailing journals, and the most productive authors displayed in form of maps produced with the assistance of VOSviewer software. Between the papers detected, it was possible to find 7 bibliometric analysis that treated the entrepreneurship and dynamic capabilities topics together. However, a deep exam on the seven papers demonstrated that most studies had the major focus on dynamic capabilities only addressing entrepreneurship related either to the entrepreneur itself or to its entrepreneurial orientation. Therefore, we conclude that entrepreneurship and dynamic capabilities are two fields of studies already consolidated by themselves but, in what concerns the research of the themes combined, they still need to have their relationships better explored. This work contributes theoretically by highlighting a relationship still underexplored at the literature, thus encouraging future studies on the theme. The practical contribution remains in offering information that may be useful to prepare managers to a most strategic and dynamic action.

\section{RESUMO}

O objetivo deste estudo foi mapear a produção acadêmica abordando os temas empreendedorismo e capacidades dinâmicas. Por meio da análise bibliométrica como método de pesquisa e usando o banco de dados WoS, encontramos 805 artigos a partir dos quais apresentamos um exame de citações, cocitações, periódicos mais prevalentes e os autores mais produtivos exibidos na forma de mapas produzidos com o auxílio do software VOSviewer Entre os artigos detectados, foi possível encontrar 7 análises bibliométricas que trataram os temas empreendedorismo e capacidades dinâmicas em conjunto. No entanto, um exame aprofundado dos sete artigos demonstrou que a maioria dos estudos teve como foco principal as capacidades dinâmicas, abordando apenas o empreendedorismo relacionado ao próprio empreendedor ou à sua orientação empreendedora. Concluímos, portanto, que empreendedorismo e capacidades dinâmicas são dois campos de estudos já consolidados por si próprios, mas, no que diz respeito à pesquisa dos temas combinados, ainda precisam ter suas relações mais bem exploradas. Este trabalho contribui teoricamente ao evidenciar uma relação ainda pouco explorada na literatura, incentivando estudos futuros sobre o tema. A contribuição prática reside em oferecer informações que possam ser úteis para preparar gestores para uma ação mais estratégica e dinâmica. 


\section{Introduction}

Entrepreneurship as a research field has been gaining prominence over the past years since its introduction over the 80 's decade. It started to gain more focus over the year of 2000, precisely when the works of Shane and Venkataraman (2000) and Sarasvathy (2001) were published at the Academy of Management Review. While the former proposed an integrating framework for the entrepreneurship field, the last assumed that entrepreneurship is a process that involves not just the individual characteristics of the entrepreneur, but the environmental characteristics that will also affect the outcomes of an entrepreneurial opportunity.

At the same time another theoretical approach was also gaining prominence at the academy over the past years, which was the concept of dynamic capabilities, that emerged from the work of Teece, Pisano and Shuen (1997). The authors define the dynamic capabilities as being "The ability that the company has to integrate, built and reconfigure internal and external competences in order to address rapidly changing markets." (Teece, Pisano and Shuen, 1997:516). The authors point out that dynamic capabilities are considered processes, which are shaped by the organization positions and its history.

The emergence of studies in dynamic capabilities is related to the efforts of researchers aiming to understand why some firms possess and sustain competitive advantage, especially in markets of unpredictable and rapid changes (Peteraf, Di Stefano and Verona, 2013). In this sense, seminal authors like Teece, Pisano and Shuen (1997) stated that the rational action of the managers had a fundamental role in innovating, which is the key challenge for organizational change.

However, it was only in 2006 that the study of Zahra, Sapienza and Davidsson (2006) proposed to join the ideas of entrepreneurship and dynamic capabilities. Their article suggests that entrepreneurs have an important role as agents of change, but that change should also be embedded in organizational routines in order to achieve a reconfiguration of the firm's resources. This study achieved such importance that according to Mota et al. (2017) the article is listed as one of the most cited references at the dynamic capabilities stream. In this sense, dynamic capabilities is a theoretical approach that interconnects with the field of entrepreneurship, mainly to the fact that dynamic capabilities and the exploitation of entrepreneurial approach are considered processes that involve not just the entrepreneur but the environment as well (Teece, 2016). For this reason, studying the interconnection of the two concepts are vital to understand an enlarge the view of how the creation and use of dynamic capabilities can help organizations to better perceive entrepreneurial opportunities, exploit them, and also undertake changes to implement new reconfigurations (Zahra, Sapienza and Davidsson, 2006; Gomes et al., 2019).

Despite of the importance of the two themes and the high number of bibliometric studies addressing the two concepts separately, the two subjects are rarely explored together as it will be demonstrated by the present study.

Aiming to map the present scenario of the scientific production based on entrepreneurship and the dynamic capabilities this bibliometric study presents an analysis of the existent literature, listing the main journals that published the themes together, the most productive authors, and the most cited references related to both matters. Afterwards clusters of keywords related to entrepreneurship and dynamic capabilities are also examined as well as other bibliometric studies that concerned the matter.

This paper contributes theoretically by addressing a relationship between two important themes and their interconnection as well as provides practical contribution, once the discussion about the relationship between dynamic capabilities and entrepreneurship can be useful to prepare managers to a most strategic and dynamic action.

Apart from this introduction, this paper is structured as follows: Section two encompasses a review of the literature that focused on the field of entrepreneurship as well as the field of dynamic capabilities. Section three details the methodological procedures of our study, followed by section four, where we discuss the results of the research. On section five we present the final considerations and on section six future research directions are provided.

\section{Literature Review}

Revista de Negócios, v. 25, n. 2, p. 34-44, April, 2020. 


\subsection{An Overview of Previous Bibliometric Studies on the Fields Separately}

According to McBurney and Novak, (2002) bibliometrics is an approach to evaluate and monitor the progress of a discipline field. As the approach relies on statistical quantification of data to have the analysis performed, such approach can only be used when a stream of research already has some sustainable literature that would provide a sample of statistical representation to perform the study (Diodato, 1994). In this sense, both entrepreneurship and dynamic capabilities considered separately, are research streams that already demonstrated such a sustainable amount of literature which resulted in a number of bibliometric papers published (Suominen, Seppanen, and Dedehayir, 2019; Apriliyanti and Alon, 2017; Dan and Goia, 2018; Santos, Marques and Ferreira, 2018).

Most studies concerning dynamic capabilities focus on the strategic management aspects like Ferrreira et al. (2017) and Vogel and Guettel (2013), demonstrating that dynamic capabilities is a research stream with different emerging perspectives such as strategic learning and organizational change. In general, it can be stated that bibliometric studies that addressed the dynamic capabilities vary within their objective, but most of them focus on addressing aspects of dynamic capabilities itself (the processes related to these capabilities).

Considering the field of entrepreneurship, the studies range from different aspects of entrepreneurship. The most recent ones focused on aspects such as regional development (Dan and Goia, 2018), female entrepreneurship (Santos, Marques and Ferreira, 2018), social entrepreneurship (Dionisio, 2019), organizational failure and decline (Kucher and FeldbauerDurstmueller, 2018), as well as ethical aspects (Vallaster et al., 2019) and internationalization (Baier-Fuentes et al., 2019).

\subsection{Bibliometric Studies on Dynamic Capabilities and Entrepreneurship Combined}

Some authors addressed the topics of dynamic capabilities and entrepreneurship as a joined issue and did conducted bibliometric studies (Gomes et al., 2019; García-Lillo et al., 2017; Mota et al., 2017; Ferreira, Fernandes and Ratten, 2016;
Vogel and Guettel, 2013; Benavides-Velasco, Quintana-García and Guzmán-Parra, 2013; Stefano, Gambardella and Verona, 2012). In the most recent study published, Gomes et al., (2019) it is possible to find an analysis related to the innovation ecosystem, in which, according to the authors, there is a research stream that draws from the previous business ecosystem literature. In this sense, although the study focusses neither on dynamic capabilities nor on entrepreneurship as its main line of inquiry it contains the concept of dynamic capabilities related to the business ecosystem literature. The concept of entrepreneurship is also mentioned and considered as on pf the the keywords of the paper.

The study of García-Líllo et al. (2017) focus on the 'born global firms', also known as 'international new ventures'. In this sense, entrepreneurship is pointed as a field of study in which this type of organization is often explored, usually with studies addressing international entrepreneurship. Dynamic capabilities, on the other hand, are simply pointed as being used as a theoretical framework in some of the studies that the authors reviewed.

The study published by Mota et al. (2017) focus specifically on the dynamic capabilities stream, aiming to map the scientific landscape from 1990 to 2015. In this sense, the authors point to an increase on the number of publications over the past few years, considering the areas of business, economics and engineering the most important. The authors highlight that the resource-based view and the neo-Schumpeterian approaches were their main theoretical roots.

In contrast Ferreira, Fernandes and Ratten (2016) focus on the broad area of strategic management which also includes the dynamic capabilities. They conclude that there is a division between strategic entrepreneurship and corporate entrepreneurship, but they do not aim to establish a relation between dynamic capabilities and entrepreneurship.

Vogel and Güttel (2013) also investigated the field of strategic management, but the authors focuses specifically at the dynamic capabilities at the strategic management field, analyzing the literature between 1994 and 2011. They highlight that the dynamic capabilities is related to learning and change capabilities, which also concerns firm performance, aspects of organization theory, and the strategic management of the organizations.

Revista de Negócios, v. 25, n. 2, p. 34-44, April, 2020. 
Entrepreneurship, on the other hand, is only slighted mentioned as the entrepreneurial behavior, which, according to the authors, is a cluster that shares a common overlap with other clusters (such as sensing opportunities, and absorbing knowledge) more specifically when it comes to ambidexterity between exploration and exploitation.

The sixth study, published by BenavidesVelasco, Quintana-García and Guzmán-Parra (2013), deals with the research field of family business, with a review of literature that ranges from 1961 to 2008. In this sense, dynamic capabilities are identified in some studies of their sample. The authors consider it as being a suitable theoretical perspective that can provide advances on the studies related to the family firms. Entrepreneurship, on the other hand, appears with more emphasis on their study since it directly connects with the scenario of family business. In this sense, the authors provide a list of journals that published more than 5 papers related to family business, in which a number of entrepreneurship journals can be identified. Examples of them are: Entrepreneurship and Regional Development (5 papers); Journal of Business Venturing (25 papers); and Entrepreneurship Theory and Practice (55 papers). Although the study does not establish a direct relationship between dynamic capabilities and entrepreneurship the high number of papers resulted in the identification of a topic named Entrepreneurship/innovation, which encompasses studies that address entrepreneurship aspects within the family business organizations.

Last but not least, the seventh study, published by Stefano, Gambardella and Verona (2012) focus on the sources of innovation for organizations. The authors address specially technology and market demands. The dynamic capability is mentioned since the authors identified they are central to their literature review. In this paper, the study of Teece, Pisano and Shuen (1997) is identified as being the most central reference to the sample collected. The authors also mention that entrepreneurship plays a central role, even though some literature addresses innovation and entrepreneurship in isolation. Nevertheless dynamic capabilities and entrepreneurship are, again, explores in isolation from each other.

\section{Methodology}

For the present study, a bibliometric research method was chosen to map the academic production addressing the themes entrepreneurship and dynamic capabilities. The approach of the study is based on statistical techniques that allows a clear visualization of the scientific field as well as produce bibliometric maps (Zupic; Čater, 2015).

Bibliometric is known as an academic stream that seeks to evaluate the research developed by a scientific community in a specific research field (Gutiérrez-Salcedo et al., 2018). In line with that, the cited authors point that bibliometric technics are methods that aim to measure the research studies using scientific publications from bibliographic databases. In this sense, the availability of data enhances the aggregate data analysis, which provides the possibility of idea creation for the researchers.

Other authors like Osareh (1996) defends that bibliometric methods seek the improvement of scientific documentation, information and communication through the quantitative analysis of the academic work collections. The cited author explains that bibliometric studies contributes to a better understanding of the scientific research field, analyzing it as set of social activities with the use of scientometrics techniques.

Table 1. Summary of bibliometric research stages

\begin{tabular}{|c|c|}
\hline Step & Activities \\
\hline $\begin{array}{c}\text { Research } \\
\text { Design }\end{array}$ & $\begin{array}{l}\text { Definition of research question; } \\
\text { Choice of the most suitable bibliographic } \\
\text { method according to the research question; } \\
\text { Definition of keywords. }\end{array}$ \\
\hline $\begin{array}{c}\text { Compilation } \\
\text { of }\end{array}$ & $\begin{array}{l}\text { Search on database; } \\
\text { Elaboration and compilation of files } \\
\text { obtained; }\end{array}$ \\
\hline $\begin{array}{c}\text { bibliometric } \\
\text { data }\end{array}$ & $\begin{array}{l}\text { Filtering and exportation of bibliographic } \\
\text { data using the Bibliometrix package for the } \\
\text { statistics software R. }\end{array}$ \\
\hline Analysis & $\begin{array}{l}\text { Data cleaning; } \\
\text { Results generation in the Bibliometrix } \\
\text { package }(\mathrm{R}) \text {; } \\
\text { Data and graphics selection. }\end{array}$ \\
\hline Visualization & $\begin{array}{l}\text { Tables and graphs development with the } \\
\text { resulting data from Bibliometrix }(\mathrm{R}) \text {; } \\
\text { Choice of the most suitable software for } \\
\text { the bibliometrics maps visualization. } \\
\text { Generation of bibliometric maps in the } \\
\text { VOSviewer; }\end{array}$ \\
\hline Interpretation & $\begin{array}{l}\text { Analysis of results considering the } \\
\text { theoretical background and the previous } \\
\text { steps of research }\end{array}$ \\
\hline
\end{tabular}

Revista de Negócios, v. 25, n. 2, p. 34-44, April, 2020. 
The citation traceability and the collaboration among researchers allow the consolidation of the bibliographic data exploration from the scientific research, as well as the orientation of these researches according to the most crucial study topics (Zupic; Čater, 2015). The authors also state that bibliometric studies are a complement, and not a substitute, of the traditional academic review methods, since it can provide analysis of academic fields by its structure, categorizing them by countries, universities, and journals. In this sense, while traditional methods focus on analyzing the subjects in a more detailed way, the bibliometric techniques can cope with a large number of studies and generate different results representations, thus encompassing a broader level of analysis. In order to reach that, this study followed some steps regarding its reliability. Table 1 summarizes the steps considered for this study.

In this sense, the present study was based on Zupic and Čater (2015) five step model. The first step initiates with the following research question: What is the present scenario of the scientific production based on entrepreneurship and the dynamic capabilities theoretical approach?

The second step consisted of defining the keywords related to the areas to be explored. For this study the keywords dynamic capabilities and entrepreneurship were chosen. Then a search was conducted on WOS and Scopus database in August 2020.

The strings "dynamic capabilit"” AND "entrepreneur*" were used at the title, abstract, keywords and keywords-plus of the papers. The types of the documents selected were "article" and "review". As a result of the search we identified 289 papers at the Scopus database, and 805 papers at WOS database. Considering the statements of Vieira and Gomes (2009), in which the authors conclude that about $2 / 3$ of published papers are available to be found in both databases, and also considering that the use of VOSviewer software is only possible applying one database (Van Eck; Waltman, 2010), we selected WoS for this study regarding the major number of researches provided.

In the third step information such as title, author, keywords, journal, year, abstract and references from the studies were gathered to analyze the bibliographical coupling network and the impact measurement of the articles. After that, the analysis was conducted by using the statistical software $\mathrm{R}$ and the bibliometrix package. At this stage, the researchers eliminated the inconsistencies of the databases, such as blank fields, and invalid data.

In the visualization step, two stages were accomplished. In the first stage we generated and compiled the statistical data from the databases using the bibliometrix package ( $\mathrm{R}$ software), were we also created tables with the most cited papers, collaboration indicators between authors, and indications of countries and research centers affiliations. On the second stage, we generatde a bibliometric map using the VOSviewer software. This software was created by Van Eck \& Waltman (2010) and enables the data graphic visualization based on labels, density, cluster mappings, and also dispersion levels. Furthermore, VOSviewer is useful once it considers the items distances from a multidimensional scaling. In this sense, the more the items are quoted together, the stronger is their relationship. Thus, the closer will be their position on the map. It also allows one to demonstrate graphically how many citations the items received individually (Van Eck; Waltman, 2010).

Finally, in the fifth step the analysis of the results was conducted and will be presented in the following chapter.

\section{Analysis and Discussion}

The first analysis performed at the bibliometric approach was to verify the concentration of articles by journals. It was identified that 88 studies $(10,4 \%)$ out of 805 documents from WoS database are from five different journals, as demonstrated at Table 1.

Table 1. Journals with most publications

\begin{tabular}{|c|c|c|c|c|c|}
\hline Year & 2016 & 2017 & 2018 & 2019 & 2020 \\
\hline $\begin{array}{ll}\text { International Business } \\
\text { Review }\end{array}$ & 1 & 2 & 3 & 3 & 2 \\
\hline ability & 0 & 1 & 7 & 8 & 6 \\
\hline $\begin{array}{l}\text { Journal of Business } \\
\text { Research }\end{array}$ & 10 & 0 & 5 & 7 & \\
\hline $\begin{array}{l}\text { Industrial Marketing } \\
\text { Management } \\
\text { Strategic }\end{array}$ & 1 & 3 & 7 & 6 & 2 \\
\hline $\begin{array}{l}\text { Entrepreneurship } \\
\text { Journal }\end{array}$ & 3 & 4 & 2 & 1 & 0 \\
\hline Total & 15 & 10 & 24 & 25 & 12 \\
\hline
\end{tabular}

Source: the authors (2020) 
Based on the results, it was also identified that the period between the 2017 and 2019 registered an increase in the number of publications. The journal that published the most was the Journal of Business Research, with 26 articles, followed by the journal Sustainability with 22 articles. The journal in third position (Industrial Marketing Management), published a special issue in October/2018 about capabilities in business relationships and networks, which resulted in the concentration of 7 publications at the year.

The second analysis performed was to identify the most cited references. The result demonstrate that the study of Teece, Pisano and Shuen (1997) prevailed and was cited in 545 documents. It was followed by the study of Eisenhardt and Martin (2000), cited in 386 documents. Table 2 displays the 20 most cited references.

Table 2. Most cited references

\begin{tabular}{|c|c|}
\hline Cited References & Citations \\
\hline $\begin{array}{l}\text { TEECE DJ, 1997, STRATEGIC MANAGE J, } \\
\text { V18, P509. }\end{array}$ & 545 \\
\hline $\begin{array}{lll}\text { EISENHARDT KM, 2000, } & \text { STRATEGIC } \\
\text { MANAGE J, V21, P1105 } & \end{array}$ & 386 \\
\hline $\begin{array}{l}\text { TEECE DJ, 2007, STRATEG MANAGE J, V28, } \\
\text { P1319. }\end{array}$ & 355 \\
\hline BARNEY J, 1991, J MANAGE, V17, P99. & 347 \\
\hline $\begin{array}{l}\text { ZAHRA SA, 2006, J MANAGE STUD, V43, } \\
\text { P917. }\end{array}$ & 207 \\
\hline $\begin{array}{l}\text { LUMPKIN GT, 1996, ACAD MANAGE REV, } \\
\text { V21, P135. }\end{array}$ & 189 \\
\hline ZOLLO M, 2002, ORGAN SCI, V13, P339. & 185 \\
\hline $\begin{array}{l}\text { COHEN WM, 1990, ADMIN SCI QUART, V35, } \\
\text { P128 }\end{array}$ & 184 \\
\hline $\begin{array}{l}\text { WINTER SG, 2003, STRATEGIC MANAGE J, } \\
\text { V24, P99. }\end{array}$ & 178 \\
\hline $\begin{array}{l}\text { FORNELL C, 1981, J MARKETING RES, V18, } \\
\text { P39. }\end{array}$ & 171 \\
\hline $\begin{array}{l}\text { PODSAKOFF PM, 2003, J APPL PSYCHOL, } \\
\text { V88, P879. }\end{array}$ & 159 \\
\hline PENROSE E, 1959, THEORY GROWTH FIRM. & 150 \\
\hline $\begin{array}{l}\text { WERNERFELT } \quad \text { B, } 1984, \quad \text { STRATEGIC } \\
\text { MANAGE J, V5, P171. }\end{array}$ & 150 \\
\hline $\begin{array}{l}\text { HELFAT C.E., } \\
\text { CAPABILITIES. }\end{array}$ & 141 \\
\hline MARCH JG, 1991, ORGAN SCI, V2, P71. & 140 \\
\hline $\begin{array}{l}\text { COVIN JG, 1989, STRATEGIC MANAGE J, } \\
\text { V10, P75. }\end{array}$ & 133 \\
\hline $\begin{array}{l}\text { NELSON R. R., 1982, EVOLUTIONARY } \\
\text { THEORY. }\end{array}$ & 117 \\
\hline MILLER D, 1983, MANAGE SCI, V29, P770. & 115 \\
\hline
\end{tabular}

ARMSTRONG JS, 1977, J MARKETING RES, V14, P396.

ZAHRA SA, 2002, ACAD MANAGE REV, V27, P185.

Source: the authors (2020)

In order to identify the most productive authors of the sample we present fractional counting and full counting method. The difference between these two counts is that while the former splits the publication weight among the number $(\mathrm{N})$ of authors with a fractional weight of $1 / \mathrm{N}$ (e.g. if a study has four authors, each one receives $1 / 4$ of the publication, or 0.25 each), the latter assumes the value of 1 for all authors of the study (PerianesRodriguez; Waltman and Van Eck, 2016).

Table 3 summarizes the 10 most productive authors. For comparison purposes we decided to maintain the authors counting with both full counting and fractional counting.

Table 3. Most productive authors

\begin{tabular}{llll}
\hline Authors & Articles & $\begin{array}{l}\text { Authors- } \\
\text { Fract }\end{array}$ & $\begin{array}{l}\text { Articles } \\
\text { Fract }\end{array}$ \\
\hline Teece DJ & 13 & Teece DJ & 9.167 \\
Zahra SA & 8 & $\begin{array}{l}\text { Zahra SA } \\
\text { Anning }\end{array}$ & 3.583 \\
Mahoney JT & 6 & Dorson T & 3.000 \\
Mcgrath H & 6 & Arend RJ & 3.000 \\
O toole T & 6 & Wang Y & 2.667 \\
Saarenketo S & 6 & Mcgrath H & 2.417 \\
Weerawardena J & 6 & O toole T & 2.417 \\
Wright M & 6 & Alonso AD & 2.333 \\
Agarwal R & 5 & Deakins D & 2.250 \\
Blesa A & 5 & Foss NJ & 2.250 \\
\hline Source: the authors $(2020)$ & &
\end{tabular}

According to the results, Teece is the most productive author, on both fractional and full counting followed by Zahra. It is interesting to point that authors like Zahra, Wright and Argawal, had studies published at a phase that was called by Landström and Benner (2010) as the "Take-off phase" of entrepreneurship.

This phase started during the $90 \mathrm{~s}$ and is known by the migration of scholars from different sciences fields to the field of entrepreneurship, on a movement called "transient researchers" (Landström and Benner, 2010).

Another analysis was conducted to verify the most productive authors over time, verifying if these 10 most productive authors were only "transient researches" or if they held a sustainable production over a longer period of time. Figure 1

Revista de Negócios, v. 25, n. 2, p. 34-44, April, 2020. 
summarizes the most productive authors with their respective year of publication, which demonstrates that most authors held a sustained production over a long period of time.

Figure 1. Authors contribution over time

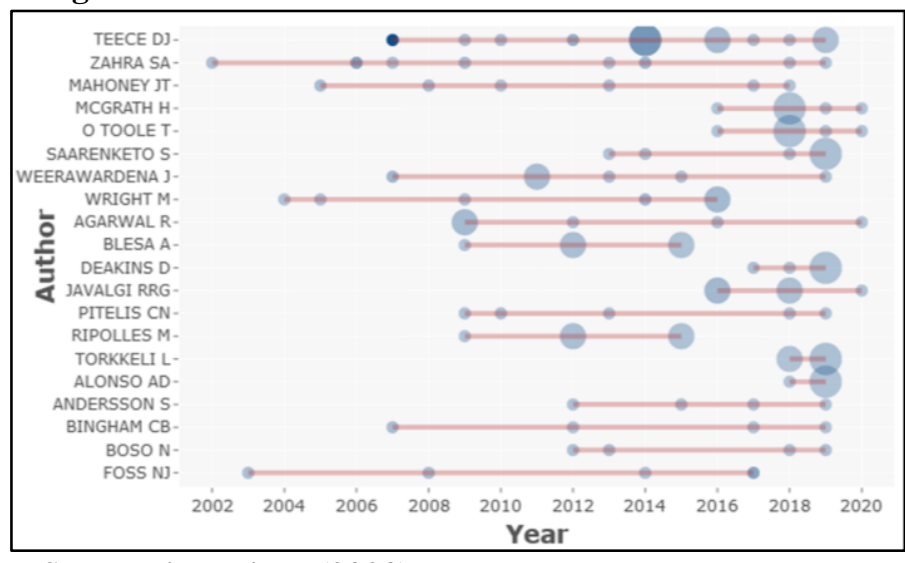

Source: the authors (2020)

Subsequently a co-citation analysis was performed, in which the 50 most cited references of the sample were identified. Figure 2 presents this analysis, in which Teece's work appears as a central reference as well.

Figure 2. Bibliometric map of co-citations

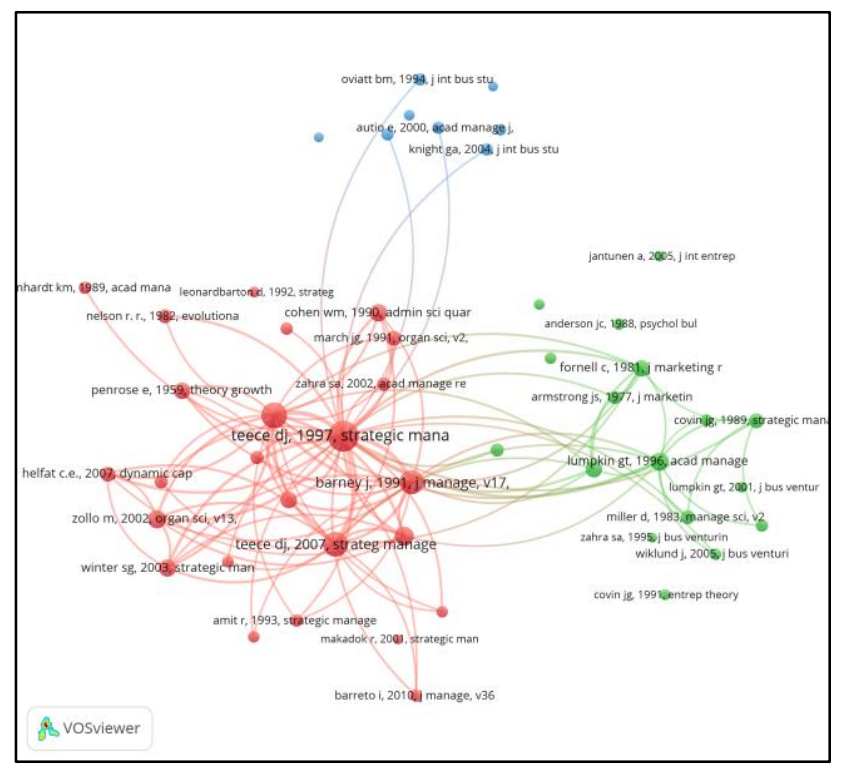

Source: the authors (2020)

The co-citation analysis was categorized under three clusters with the assistance of the software VOSviewer which is based on the characteristics of the papers. The red cluster located at the left includes authors from a classical strategy research stream, such as Nelson (1982), Penrose (1959), and Barney (1991). Those authors represent a group of scholars that influenced the seminal works of the dynamic capability stream such as Teece, Pisano and Shuen (1997) and Teece (2007) which are two of the most expressive works of the sample. In this sense, this cluster is represented by a predominance of scholars related to the seminal works of dynamic capabilities, including scholars from the resource based theory, and other seminal works of the strategic management stream.

On the right side of the map, the green cluster displays papers related to the entrepreneurship field, such as Lumpkin and Dess (1996). Nevertheless, other authors with researches that do not directly relate to entrepreneurship can also be identified in the cluster, such as Fornell and Larcker (1991) and Covin and Slevin (1989). These authors are related to the strategy field. These cluster thus represents studies that are related to the dynamic capabilities studies.

Finally, the third cluster is displayed in blue, located at the top of the map. This group of authors contains studies that deals with dynamic capabilities aspects, such as organizational capabilities, born-global firms, imitability, international growth, and new ventures. This cluster displays authors related to the aspects of international business research and is also related to the main cluster of dynamic capabilities.

The results displayed at figure 2 suggests that dynamic capabilities is a stream with a large amount of influence on the sample which can also be observed in the authors' contribution analysis.

Another analysis conducted was the keyword relationship between the studies. Thus, from the 805 studies of the sample, 1690 keywords were identified. Figure 3 summarizes the keywords that had 7 or more citations, which resulted in 50 keywords.

Figure 3 demonstrates three distinct clusters. The red cluster located on the right bottom left contains keywords more related to the field of dynamic capabilities once the keyword 'dynamic capabilities' is the central keyword. This cluster also contains keywords such as performance and firm and management. These subjects are often related to the organizational strategy aspects and are directly related to the dynamic capability and strategic management approaches. 
Figure 3. Bibliometric map of the 50 most cited keywords

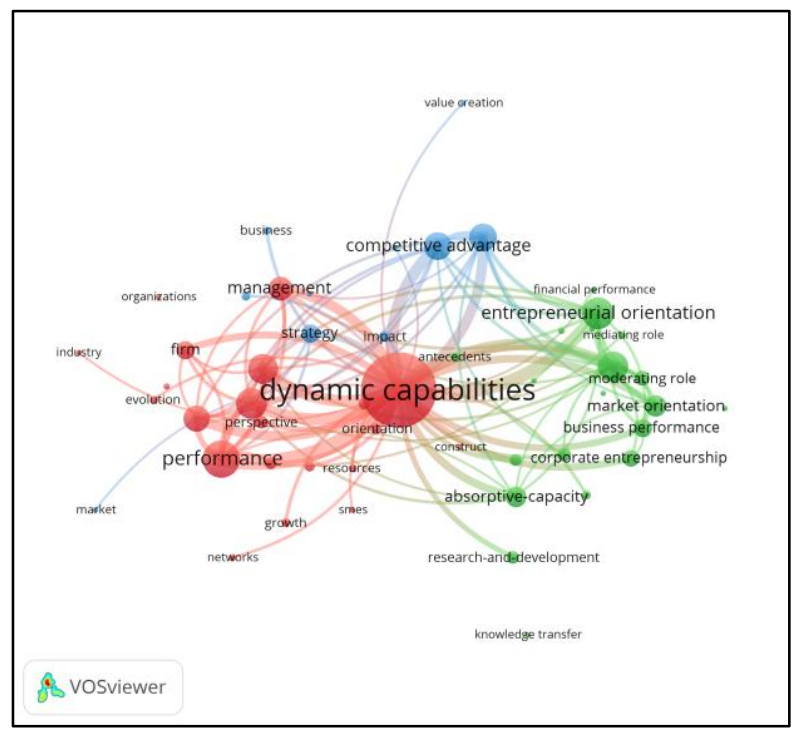

Source: the authors (2020)

In contrast, the green cluster, displayed on the right side of the map, contains keywords related to the entrepreneurship field, with the keyword entrepreneurial orientation being one of the most expressive one. In this cluster, other keywords like corporate entrepreneurship and market orientation also appear and are related to the entrepreneurship field.

Lastly, at the top of the map the blue cluster shows the keyword 'competitive advantage' as the most expressive evidence. It contains studies addressed mainly to international ventures literature.

In sum, the results demonstrate that the major part of the studies used in this sample are related directly to the dynamic capabilities stream. This is evidenced by the authors contribution analysis and also in the analysis of the maps of co-citation and keywords. The findings testify that dynamic capabilities were a central point for the studies analyzed.

Even considering the analysis of the keywords map, in which it was possible to notice a cluster that emphasizes the entrepreneurship field, most of the keywords are directly related to dynamic capabilities revealing the predominance of this field in comparison to the entrepreneurship one.

Furthermore, it is possible to extract from the map of co-citation that Teece as first author (1997; 2016) are the most preeminent, although, despite of the unquestionable importance of the author, his approach tends to limit the analysis of entrepreneurship, once it concentrates mainly on the person of the entrepreneur. Based on this evidence, we argue that such approach could lead to a constrained view of entrepreneurship.

On top of all, the analysis of the 7 bibliometric studies addressing dynamic capabilities within the entrepreneurship field evidenced that their content was explored in a way that isolated the fields from each another. In this sense we also argue that the two research fields could have their relationships better explored and articulated leaving space for deeper immersion. In addition, the creation of new theoretical models involving the issues related to dynamic capabilities and entrepreneurship could be also prospected.

\section{Conclusion and Final Considerations}

The results of the present study demonstrated that despite the great number of papers dealing with entrepreneurship and dynamic capabilities there is still a theoretical gap concerning researches that addresses the two of the field in an integrated way.

As evidenced in the findings there is some predominance of the dynamic capability over the entrepreneurship field that tends to treat the entrepreneurship only by its entrepreneur's feature, setting aside other perspectives of this field study.

As previously demonstrated, the few authors who intended to address both fields though bibliometric analysis did not accomplished that in an interrelated way. Thereby, given the complementary roles of dynamic capabilities and entrepreneurship, it is important to advance in the understandings of the topics together as well as the theoretical and empirical level.

Finally, this study has some contributions both to literature and to practicing. First by offering a unique bibliometric analysis that seek to interconnect both the entrepreneurship and the dynamic capabilities approach, as it was evidenced in the results, is rare to be found. Second, by pointing the gaps that still remain between these two important areas of knowledge. Third by encouraging future studies that could reach the underexplored gaps among dynamic capabilities and entrepreneurship. And finally, we expect that the information and the discussion contained in this study may provide managers with information that can lead to a most strategic and dynamic action.

\section{Implications and Further Research}

Revista de Negócios, v. 25, n. 2, p. 34-44, April, 2020. 
This research has limitations such as its quantitative method, which does not contemplate a deep analysis of content of all the 805 articles, but only on their main information. To reach a more profound analysis we suggest that future researchers conduct a qualitative review or even a meta-synthesis of the content.

Another limitation refers to the fact that only one database was used for the study. For this reason, relevant papers may have been missed. To overcome this limit, we suggest that future researches deal with a combination of different softwares that can enable the use of more than one database per analysis.

Finally, we argue that studies involving entrepreneurship and the dynamic capability theoretical approach is a fertile area for both theoretical and empirical studies. We are looking forward to future studies that can surpass our constraints and bring advances to this significant area of study.

\section{References}

Apriliyanti I. D.\& Alon I. (2017). Bibliometric analysis of absorptive capacity. International Business Review, 26(5), 896-907.

Aria, M.\& Cuccurullo, C. (2017). Bibliometrix: An R-tool for comprehensive science mapping analysis. Journal of Infometrics, 11(4), 959-975.

Baier-Fuentes, H.; Merigo, J. M.\& Amorós, J. E.; Gaviria-Marin M. (2019). International entrepreneurship: a bibliometric overview. International Entrepreneurship and Management Journal, 15, 385-429.

Barney, J. (1991). Firm Resources and Sustained Competitive Advantage. Journal of Management

Barreto, I. (2010). Dynamic capabilities: a review of past research and an agenda for the future.

Journal of Management, 36(1), 256-280.

Benavides-Velasco, C. A.; Quintana-García, C.\& Guzmán-Parra, V. F. (2013). Trends in family business research. Small Business Economics, 40 (1), 41-57.

Covin, J.G. and Slevin, D.P. (1989), Strategic management of small firms in hostile and benign environments. Strategic Management Journal, 10: 75-87.
Dan, M. C. \& Goia, S. I. Entrepreneurship and regional development. A bibliometric analysis (2018). In: Proceedings of the International Conference on Business Excellence. 12 (1), 276287.

Diodato, V. (1994). Dictionary of bibliometric. Haworth Press: Binghamton.

Dionisio. M. (2019). The evolution of social entrepreneurship research: a bibliometric analysis. Social Entrepreneurship Journal. 15(1), 22-45.

Eisenhardt, K. M. \& Martin, J. A. (2000). Dynamic Capabilities: What are they? Strategic Management Journal, 21, 1105-1121.

Fereira, J. J.; Raposo, M. L.; Estevão, C.; PerisOrtiz, M.\& Rueda-Armengot, C. (2017). The dynamic capabilities perspective of strategic management: a co-citation analysis.

Scientometrics, 112(1), 529-555.

Ferreira, J. J. M. \& Fernandez, C. I.; Ratten, V. (2016). A co-citation bibliometric analysis of strategic management research. Scientometrics, 109(1), 1-32.

Fornell, C., \& Larcker, D. (1981). Evaluating Structural Equation Models with Unobservable Variables and Measurement Error. Journal of Marketing Research, 18(1), 39-50.

García-Lillo, F., Claver-Cortés, E., Marco-Lajara, B. \& Mercedes Úbeda-García. (2017). Mapping the Intellectual Structure of Research on 'Born Global' Firms and INVs: A Citation/Co-citation Analysis. Management International Review, 57, 631-652.

Gomes, L. A. de V.; Facin, A. L. F.; Salerno, M. S.\& IkenamI, R. K. (2018). Unpacking the innovation ecosystem construct: Evolution, gaps and trends. Technological Forecast \& Social Change, 136, 30-48.

Gutiérrez-Salcedo, M., Martínez, M. Á., MoralMunoz, J. A., Herrera-Viedma, E., \& Cobo, M. J. (2018). Some bibliometric procedures for analyzing and evaluating research fields. Applied Intelligence, 48(5), 1275-1287. https://doi.org/10.1007/s10489-017-1105-y

Kücher, A. \& Feldbauer-Durstmüller, B. (2018). Organizational failure and decline - A bibliometric study of the scientific frontend. Journal of Business Research, 98, 503-516. 
Landström, H. \& Benner, M. (2010).

Entrepreneurship research: a history of scholarly migration. In: Historical Foundations of Entrepreneurship Research. 13-45. Edward Elgar:Cheltenham.

Lumpkin, G. T. \& Dess, G. G. (1996). Clarifying the Entrepreneurial Orientation Construct and Linking It to Performance. The Academy of Management Review, 21 (1), 135-172.

Mcburney, M. K. \& Novak, P. L. (2002). What is bibliometric and why should you care? In: Proceedings of the professional communication conference. 108-114.

Mota, F. B.; Pinto, C. D.; Paranhos, J. \& Hasenclever, L. (2017). Mapping the 'dynamic capabilities' scrientific landscape, 1990-2015: A bibliometric analysis. Journal of Scientometrics and Information Management, 11(2), 309-324.

Nelson, R. R., \& Winter, S. G. (1982). An evolutionary theory of economic change. Cambridge MA Belknap (Vol. 93).

Osareh, F. (1996). Bibliometrics, Citation Analysis and Co-Citation Analysis: Libri, 46, 149-158.

Penrose, E. (1959). Teoria do crescimento da firma. Oxford: Oxford Scholarship.

Perianes-Rodriguez, A.; Waltman, L. \& Van Eck, N. J. (2016). Constructing bibliometric networks: A comparison between full and fractional counting. Journal of Informetrics, 10 (4), 11781195.

Peteraf, M., Di Stefano, G., \& Verona, G. (2013). The elephant in the room of dynamic capabilities: bringing two diverging conversations together. Strategic Management Journal, 34(April), 13891410.

Santos, G.; Marques, C. S.; Ferreira, J (2018). A look back over the past 40 years of female entrepreneurship: mapping knowledge networks. Scientometrics, 115(2), 953-987.

Sarasvathy, S. D. (2001). Causation and Effectuation: Toward a theoretical shift from economic inevitability to entrepreneurial contingency. Academy of Management Review, 26(2), 243-263.

Shane, S. \& Venkataraman, S. (2000). The promise of entrepreneurship as a field of research.
Academy of Management Review, 25(1), 217-226.

Stefano, G. D.; Gambardella, A. \& Verona, G. (2012). Technology push and demand pull perspectives in innovation studies: Current findings and future research directions. Research Policy, 41(8), 1283-1295.

Suominen A.; Seppänen, M. \& Dedehayir. (2019).A bibliometric review on innovation systems and ecosystems: a research agenda. European Journal of Innovation Management, 22(2), 335-360.

Teece, D. J. (2012). Dynamic Capabilities: Routines versus Entrepreneurial Action. Journal of Management Studies, 49(8), 1395-1401.

Teece, D. J. (2016). Dynamic capabilities and entrepreneurial management in large organizations: Toward a theory of the (entrepreneurial) firm. European Economic Review, 86, 202-216.

Teece, D. J. (2007). Explicating Dynamic Capabilities: The Nature and Microfoundations of Sustainable Enterprise Performance. Strategic Management Journal, 28, 1319-1350.

Teece, D. J. \& Pisano, G. (1994). The dynamic capabilities of enterprise: an introduction. Industrial and Corporate Change, 3(3), 537-556.

Teece, D. J.; Pisano, G. \& Shuen, A. (1997). Dynamic Capabilities and Strategic Management. Strategic Management Journal, 18(7), 509-533.

Teece, D., Peteratd, M., \& Leih, S. (2016). Dynamic Capabilities and Organizational Agility. California Management Review, 58(4), 4-9.

Vallaster, C. \& Kraus, S. (2019). Ethics and Entrepreneurship: A Bibliometric Study and Literature Review. Journal of Business Research, 99, 226-237.

Van Eck, N. J. \& Waltman, L. (2010). Software survey: VOSviewer, a computer program for bibliometric mapping. Scientometrics, 84(2), 523538.

Vieira, E. S., Gomes, J. A. N. F., 2009. A comparison of Scopus and Web of Science for a typical university. Scientometrics, 81, 587-600.

Voegel, R. \& Güttel, W. H. (2013). The Dynamic Capability View in Strategic Management: A Bibliometric Review. International Journal of 
Management Reviews, 15(4), 426-446.

Wernerfelt, B. (1984). A resource-based view of the firm. Strategic Management Journal, 5(2), 171-180.

Zahra, S. A., Sapienza, H. J., \& Davidsson, P. (2006). Entrepreneurship and Dynamic

Capabilities: A Review, Model and Research Agenda. Jornal of Management Studies, 43(3), 917-955.

Zollo, M. \& Winter, S. G. (2002). Deliberate Learning and the Evolution of Dynamic Capabilities. Organization Science, 13(3), 339351.

Zupic, I., \& Čater, T. (2015). Bibliometric Methods in Management and Organization. Organizational Research Methods, 18(3), 429472. 